\title{
Pengembangan Modul Bahasa Indonesia dengan Pendekatan Local Wisdom pada Materi Menulis Karangan Narasi untuk Siswa SD
}

\author{
Hanum Hanifa Sukma ${ }^{1 *}$, Ganis Amurdawati \\ ${ }^{1}$ Program Studi Pendidikan Guru Sekolah Dasar, Universitas Ahmad Dahlan, Yogyakarta, Indonesia \\ ${ }^{2}$ Program Studi Pascasarjana Pendidikan Dasar, Univertas Negeri Semarang, Semarang, Indonesia
}

Pengiriman: 08/02/2020; Diterima: 23/10/2020; Publikasi: 20/11/2020

DOI: 10.31629/kiprah.v8i2.1991

\begin{abstract}
Abstrak
Modul dalam pembelajaran Bahasa Indonesia menjadi pendukung siswa dalam menguasai materi sebab materi bahasa Indonesia saat ini diorientasikan berbasis teks. Tujuan pengembangan bahan ajar berbentuk modul ini untuk menghasilkan bahan ajar modul berbasis local wisdom yang layak pada materi menulis karangan narasi. Jenis penelitian ini adalah penelitian pengembangan atau Reseach and Development. Pengembangan mengacu pada model pengembangan ADDIE (Analyse, Design, Development, Implementation and Evaluation). Namun, pengembangan ini hanya sampai tahap implementation dan tahap kelima tidak dilakukan karena keterbatasan waktu dan biaya. Implementasi dilakukan pada salah satu sekolah dasar dengan subjek 28 siswa. Teknik pengumpulan data dalam penelitian ini menggunakan angket. Data yang didapatkan dianalisis dengan deskriptif persentase. Hasil dari validasi modul oleh ahli materi dan pembelajaran terdiri dari aspek kelayakan isi sebesar $89 \%$, aspek kebahasaan $87 \%$, dan aspek sajian $82 \%$. Sementara itu, penilaian produk oleh ahli media meliputi aspek bahan ajar sebesar $83 \%$, aspek gambar/kegrafikan sebesar $81 \%$, dan aspek tampilan sebesar $82 \%$. Hasil uji coba terbatas mendapat respon positif sebesar $98,25 \%$ sehingga modul sangat layak digunakan sebagai bahan ajar. Penelitian ini menghasilkan pengembangan bahan ajar modul yang berbasis local wisdom di sekitar siswa yang menjadikan inovasi dalam mengembangkan kemampuan menulis narasi.
\end{abstract}

Kata kunci: ADDIE; local wisdom; modul; teks narasi

\begin{abstract}
The position of Indonesian Language subjects in the 2013 Curriculum is an intermittent interrelation of other subjects in the learning process, in addition to that the Indonesian language material is currently oriented based on text. The purpose of developing teaching materials is to form modules to produce module teaching materials based on local wisdom in writing narrative essays for fifth grade students to find out the level of feasibility of the modules developed in writing local narrative essay writing materials. This type of research is development research or research and development. An interesting development in the ADDIE development model (Analysis, Design, Development, Implementation and Evaluation). However, this development only reached implementation, and the completion was not carried out due to time and cost limitations. Implementation was carried out in one of the elementary schools with a subject of 28 students. The technique of collecting data in this study used a questionnaire. The data obtained were analyzed with descriptive percentages. The results of the module validation by subject matter and learning experts consisted of $89 \%$ content eligibility aspects, $87 \%$ linguistic aspects, and $82 \%$ presentation aspects. Meanwhile, media experts released products with $83 \%$ teaching aspect, $81 \%$ picture / graphic aspect and $82 \%$ visual aspect. The limited trial results received a positive response of $98.25 \%$ so that the module is very feasible to use as teaching material. Teaching material based
\end{abstract}


development modules based on local wisdom among students become an innovation in developing narrative writing skills.

Keywords: ADDIE; local wisdom; module; narrative text

\section{PENDAHULUAN}

Bahasa Indonesia merupakan salah satu mata pelajaran yang harus dikuasai siswa Sekolah Dasar. Empat keterampilan bahasa yang harus dikuasai siswa adalah mendengarkan, berbicara, membaca, dan menulis. Salah satu keterampilan yang dilatihkan kepada siswa adalah keterampilan menulis. Keterampilan menulis di SD akan membentuk keterampilan dasar yang memengaruhi keterampilan menulis pada tingkat selanjutnya.

Keterampilan menulis diharapkan membentuk siswa SD agar mampu berkomunikasi secara tertulis dengan baik dalam kehidupannya. Solcan dkk (2011: 9) menyatakan bahwa pengajaran menulis di SD kelas tinggi difokuskan pada latihan berkomunikasi dengan menggunakan bahasa tulis secara jelas. Jadi, pengajaran bahasa Indonesia khususnya keterampilan menulis harus sesuai dengan tingkat jenjang pendidikan siswa sehingga mampu mengembangkan kemampuan siswa secara optimal.

Menulis merupakan aktivitas menurunkan atau melukiskan lambanglambang grafik yang menggambarkan suatu bahasa yang dipahami oleh seseorang sehingga orang lain dapat membaca lambang-lambang grafik tersebut (Tarigan, 2008: 22). Menulis dapat didefinisikan sebagai suatu kegiatan penyampaian pesan (komunikasi) dengan menggunakan bahasa tulis sebagai alat medianya (Suparno dan M. Yunus, 2008: 3). Menulis merupakan kegiatan yang membantu siswa dalam mentransfer materi pembelajaran ke dalam tulisan. Hal ini dapat mendorong siswa untuk terampil dalam menulis.

Keterampilan menulis tingkat lanjut memerlukan pelatihan yang sistematis serta instruksi perhatian eksekutif sehingga dapat mengoordinasikan dan merepresentasikan proses penulisan (Kellog, 2008). Dalam hal ini untuk mengembangkan kemampuan siswa dalam menulis dibutuhkan sebuah intruksi khusus untuk mendorong siswa menulis. Terutama untuk siswa SD, instruksi khusus yang diberikan oleh guru dalam kinerja menulis sangat penting untuk menghasilkan tulisan yang baik. Sementara itu, Cutler \& Graham (2008) menemukan bahwa sebagian besar guru sekolah dasar mengambil pendekatan eklektik untuk instruksi menulis, menggabungkan elemen dari dua metode paling umum untuk mengajar menulis: proses penulisan dan instruksi keterampilan. Intruksi menulis sangat berguna bagi siswa untuk terampil dalam menulis berbagai teks dalam segi kehidupannya pada masa mendatang.

Pada pembelajaran di sekolah dasar, kemampuan siswa dalam menulis dihadirkan dengan berbagai macam jenis teks, salah satunya adalah menulis karangan naratif. Tugas menulis naratif efektif dalam memunculkan kata-kata hidup dan sintaksis kompleks pada anak-anak usia sekolah dan remaja (Sun \& Nippold, 2012). Curenton (2010) memaparkan bahwa siswa lahir tidak disertai dengan kemampuan untuk membuat dan memahami cerita sehingga kemampuan narasi siswa dipelajari dari waktu ke waktu melalui interaksi yang terkandung budaya dari anggota keluarga, guru, teman sebaya, dan buku/bentuk media lainnya.

Narasi merupakan suatu bentuk wacana yang berusaha mengisahkan suatu kejadian atau peristiwa sehingga tampak seolah-olah pembaca melihat atau mengalami sendiri peristiwa itu. Oleh karena itu, unsur yang paling penting pada sebuah narasi adalah unsur perbuatan atau tindakan (Keraf, 2007: 135).

Dalam pemenuhan untuk menunjang siswa menulis karangan naratif, diperlukan 
sebuah bahan ajar yang terstuktur dan mendukung. Sugiyono (2014) menyatakan bahwa pengembangan bahan ajar harus memerhatikan tiga prinsip, yaitu berpusat pada siswa, tingkat berpikir siswa, dan fleksibilitas. Sementara itu, hasil penelitian Nisa (2019) memaparkan bahwa bahan ajar bahasa Indonesia berdasarkan kontekstual cocok untuk digunakan sebagai buku pendamping dalam belajar. Asip, dkk. (2019) mengatakan bahwa pengembangan cerita rakyat menjadi bahan ajar adalah langkah untuk mendukung kegiatan literasi membaca di sekolah dasar. Salah satu alternatif bahan ajar yang berupa modul.

Permasalahan ditemukan akan kebutuhan bahan ajar untuk mengarahkan siswa dalam menulis karangan di sekolah dasar. Hal tersebut berimbas pada kendala yang dihadapi siswa dalam menguasai keterampilan menulis terutama menulis karangan narasi. Banyak siswa yang sulit mengembangkan karangan menjadi satu bentuk paragraf utuh. Permasalahan lain adalah sulitnya siswa membedakan jenis paragraf. Mereka sulit membedakan antara pargraf narasi dengan paragraf deskripsi. Padahal pada kurikulum 2013 saat ini siswa dituntut untuk membaca dan menulis yang menjadi sebuah kegiatan inti dalam pembelajaran.

Untuk menjawab permasalahan di atas, dibutuhkan sebuah bahan ajar yang mampu menjadi alternatif bagi siswa dan guru untuk digunakan dalam pembelajaran keterampilan menulis karangan narasi dengan sebuah intruksi-intruksi yang jelas. Salah satu bentuk bahan ajar yang dapat digunakan oleh siswa dan guru Sekolah Dasar adalah modul. Hasil dari penelitian Anwar, dkk. (2017) modul pembelajaran tematik terpadu berbasis kearifan lokal Kabupaten Sumenep kelas IV subtema Lingkungan Tempat Tinggalku menghasilkan modul yang memiliki kevalidan dan keefektivan sehingga layak digunakan. Modul merupakan bahan ajar yang disusun secara sistematis dengan bahasa yang mudah dipahami oleh siswa, sesuai usia dan tingkat pengetahuan mereka agar mereka dapat belajar secara mandiri dengan bimbingan minimal dari pendidik (Andi Prastowo, 2012: 106). Deviana (2018) menjelaskan bahwa modul merupakan salah satu jenis dari bahan ajar cetak yang dapat digunakan untuk belajar secara mandiri dan memuat konsep bahan pengajaran yang dapat dipelajari sendiri oleh siswa (self instruction), dengan begitu siswa akan aktif belajar (active learning).

Penggunaan modul berpotensi untuk memberikan fasilitas bahan ajar siswa sebagai penunjang dalam mengembangkan keterampilan menulis karangan narasi. Telah banyak pengembangan modul yang berorientasi dengan tujuan yang hendak dicapai dari landasan pengembangan tersebut. Hal ini menjadi daya dukung dari pengembangan modul sebagai salah satu alternatif bahan ajar yang dapat digunakan siswa untuk menulis karangan narasi dengan mendorong perkembangan keterampilannya dalam menulis.

Dalam pengembangan modul, integrasi pilihan materi menjadi salah satu pertimbangan. Kurikulum 2013 selain penggunaan pendekatan saintifik juga melibatkan lingkungan sekitar dan kehidupan sehari-hari siswa sebagai sumber belajar. Dalam hal ini menjadi potensi terintegrasinya kearifan lokal yang ada di sekitar siswa. Pemberian konten lokal dalam pendidikan sangat penting untuk mengisi elemen budaya dan itu membuat daya tahan budaya dari era globalisasi (Saputra, 2013). Dengan demikian, mengangkat kearifan lokal ke dalam sebuah materi pembelajaran mampu membawa siswa mengenal lebih dekat potensi yang ada di sekitarnya dan mempertahankan kearifan lokal tersebut dari arus globalisasi yang ada.

Berdasarkan berbagai analisis kebutuhan terkait dengan pentingnya keterampilan menulis karangan narasi, penelitian tentang pengembangan modul menulis karangan narasi sebagai bahan ajar dapat dilakukan dengan tujuan untuk mendorong siswa dan memberikan fasilitas dalam mengembangkan keterampilan 
menulisnya. Pengembangan ini berbasis dengan local wisdom yang ada di Yogyakarta sebagai materi yang termuat di dalam modul.

\section{METODE PENELITIAN}

Rancangan penelitian yang digunakan merupakan jenis penelitian pengembangan atau research and development $(\mathrm{R} \& \mathrm{D})$ dengan desain ADDIE (analysis, design, development, implementation, and evaluation). Model ADDIE dikembangkan oleh Dick and Carry untuk merancang sistem pembelajaran (Mulyatiningsih, 2012:5). Adapun desain pada gambar 1 .

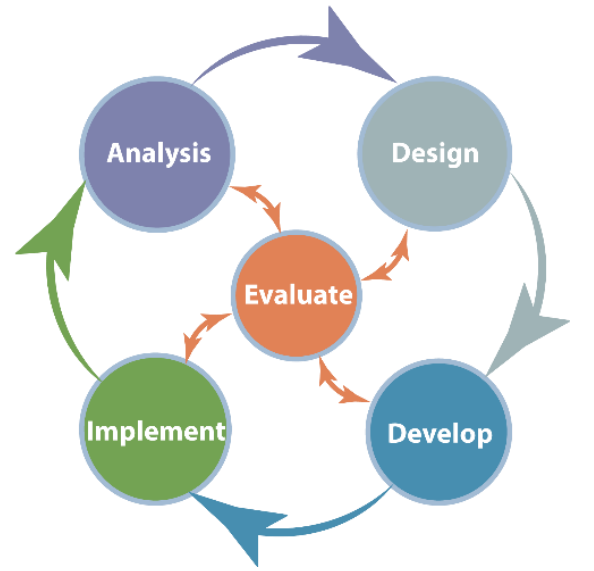

Gambar 1. Desain ADDIE

Namun, tahapan hanya sampai pada implementasi uji coba skala kecil. Subjek uji coba adalah ahli materi dan pembelajaran, ahli media dan ahli bahasa, serta 28 siswa kelas V di Sekolah Dasar. Teknik pengumpulan data menggunakan angket validasi produk dengan mengadaptasi aspek-aspek yang harus dipenuhi dalam penyusunan bahan ajar (Depdiknas, 2008: 28) . Adapun Teknik analisis data dengan menghitung total peroleh skor pada angket kemudian diubah ke dalam presentase. Persentase tersebut diperoleh dengan berdasarkan perhitungan skor menurut Skala Likert (Riduwan, 2012) dengan keterangan skala penilaian untuk validasi ahli yaitu "4" bernilai sangat baik, "3" bernilai baik, " 2 " bernilai tidak baik, dan "1" bernilai sangat tidak baik. Adapun kriteria penilaian produk dapat dilihat pada Tabel 1.
Tabel 1. Kriteria Penilaian Produk

\begin{tabular}{lc}
\hline \multicolumn{1}{c}{ Rentang skor $(i)$ kuantitatif } & $\begin{array}{c}\text { Kriteria } \\
\text { kualitatif }\end{array}$ \\
\hline$X>\left(\bar{X}_{i}+1,8 \mathrm{sb} i\right)$ & Sangat baik \\
\hline$\left(\bar{X}_{i}+0,6 \mathrm{sb} i\right)<X \leq\left(\bar{X}_{i}+1,8 \mathrm{sb} i\right)$ & Baik \\
\hline$\left(\bar{X}_{i}-0,6 \mathrm{sb} i\right)<X \leq\left(\bar{X}_{i}+0,6 \mathrm{sb} i\right)$ & Cukup \\
\hline$\left(\bar{X}_{i}-1,8 \mathrm{sb} i\right)<X \leq\left(\bar{X}_{i}-0,6 \mathrm{sb} i\right)$ & Kurang \\
\hline$X \leq\left(\bar{X}_{i}-1,8 \mathrm{sb} i\right)$ & Sangat kurang \\
\hline
\end{tabular}

(Widoyoko, 2009: 238)

Modul dikembangkan dengan berbantuan bahan dan alat yang mendukung. Modul berbentuk media cetak dengan ukuran ketas Kuarto berbahan ivory. Disusun dengan menggunakan Bahasa Indonesia. Disusun dengan menggunakan bantuan program Microsoft Word 2010, Corel Draw X3 dan Paint. Disusun berdasarkan Kurikulum 2013 yang berlaku di sekolah Materi modul yaitu menulis karangan narasi dengan berbasis local wisdom.

\section{HASIL DAN PEMBAHASAN Hasil Penelitian}

Hasil pengembangan modul Bahasa Indonesia dengan menulis karangan narasi berbasis local wisdom dikembangkan dengan desain ADDIE (Analysis, Design, Development, Implementation, Evaluation). Tahap pertama adalah analisis, pada tahapan ini dilakukan analisis kurikulum pada pelajaran bahasa Indonesia terutama pada materi atau pokok bahasan menulis karangan narasi. Analisis kurikulum tersebut meliputi kompetensi inti, kompetensi dasar, dan indikator-indikator lainnya. Analisis dari hasil observasi juga menjadi pertimbangan. Dari hasil analisis ini dapat diketahui beberapa bahan ajar yang diperlukan dan disiapkan untuk kegiatan pembelajaran dan jenis bahan ajar yang akan digunakan/dipilih. Analisis ini merupakan dasar dalam pengembangan modul yang akan disusun. Di samping itu juga dilakukan analisis terhadap karakteristik pengguna modul. Adapun hasil dari pemetaan analisis ditampilkan pada Tabel 2. 
Tabel 2. Hasil Analisis Kurikulum

\begin{tabular}{l} 
Kompetensi Inti \\
1.1 Menerima dan menjalankan ajaran agama \\
yang dianutnya. \\
1.2. Menunjukkan perilaku jujur, disiplin, \\
tanggung jawab, santun, peduli, dan percaya diri \\
dalam berinteraksi dengan keluarga, teman, \\
guru, dan tetangga. \\
2.3. Memahami pengetahuan faktual dengan \\
cara mengamati (mendengar, melihat, membaca) \\
dan menanya berdasarkan rasa ingin tahu \\
tentang dirinya, makhluk ciptaan Tuhan dan \\
kegiatannya, serta benda-benda yang \\
dijumpainya di rumah dan di sekolah. \\
3.4. Menyajikan pengetahuan faktual dalam \\
bahasa yang jelas, sistematis dan logis dalam \\
karya yang estetis, dalam gerakan yang \\
mencerminkan anak sehat, dan dalam tindakan \\
yang mencerminkan perilaku anak \\
beriman dan berakhlak mulia. \\
\hline Kompetensi Dasar Bahasa Indonesia \\
3.5 Membangun pendapat pribadi tentang isi \\
buku sastra (cerita, dongeng, dan sebagainya). \\
4.5 Mengomunikasikan secara lisan dan tulisan \\
pendapat pribadi tentang isi buku sastra yang \\
dipilih sendiri dan dibaca yang didukung oleh \\
alasan. \\
Indikator: \\
3.5.1 Membuat garis besar pendapat pribadi \\
tentang buku sastra (cerita, dongeng, dan \\
sebagainya). \\
4.5.1 Mengemas secara lisan dan tulisan \\
pendapat pribadi tentang isi buku sastra yang \\
dipilih sendiri dan dibaca yang didukung oleh \\
alasan \\
4.4.2 Mempertajam pengetahuan dengan kreasi \\
menulis teks karangan narasi \\
\hline
\end{tabular}

Tahap selanjutnya dalah tahap desain. Pada tahap ini dilakukan penyusunan modul yang meliputi peta kedudukan modul, judul modul, dan penulisan modul. Selanjutnya, menyusun struktur modul yang memuat judul, petunjuk belajar (petunjuk siswa), kompetensi yang akan dicapai, informasi pendukung, tugas-tugas dan langkah kerja dan evaluasi/penilaian. Hasil dari tahap ini ditampilkan pada Gambar 2.

\section{PETA KEDUDUKAN MODUL}

TEMA 1 BERBAGAI PEKERJAAN
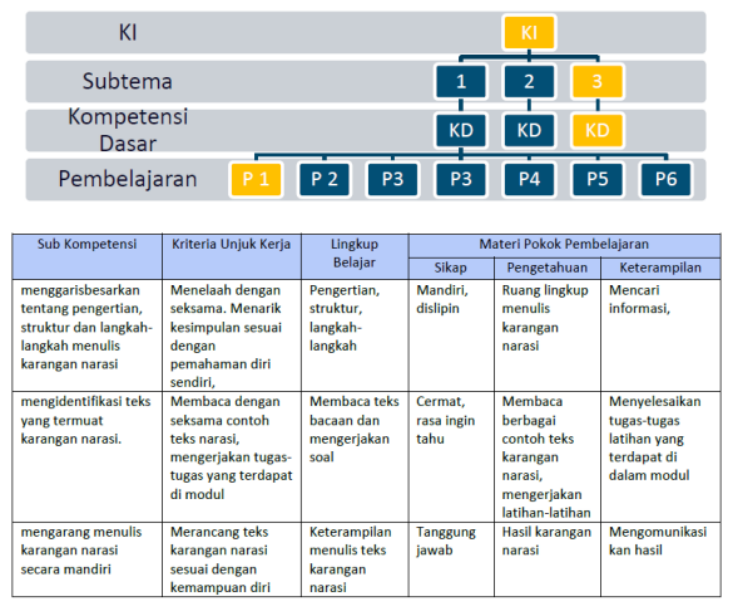

Gambar 2. Peta Kedudukan Modul \& Kompetensi

Tahap selanjutnya adalah pengembangan. Tahap pengembangan meliputi kegiatan pembuatan modul. Setelah ditentukan kerangka penyusunan modul, langkah selanjutnya adalah menentukan produk modul. Modul yang disusun memperhatikan syarat kualitas berikut; a) Aspek Kelayakan Isi; b) Aspek Kebahasaan c) Aspek Penyajian dan d) Aspek Local wisdom. Hasil dari pengembangan modul ditampilkan pada Gambar 3.

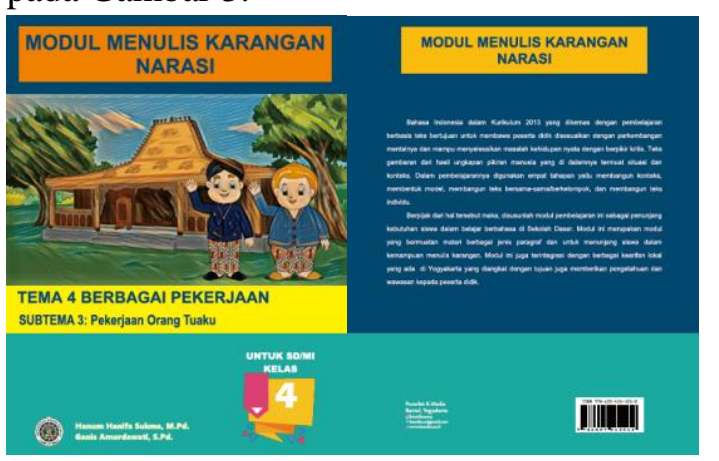

Gambar 3. Tampilan Sampul Modul

Tahap berikutnya adalah implementasi. Ini merupakan tahap terakhir dari pengembangan modul yang dilakukan peneliti karena keterbatas waktu dan biaya sehingga tidak sampai pada tahap evaluasi. Pada tahap implementasi sebelumnya modul divalidasi oleh ahli terkait dengan kelayakan modul kemudian dilakukan uji coba yang terbatas yakni pada kelompok kecil yang terdiri dari 28 siswa di kelas V. Implementasi 
untuk uji coba modul ditampilkan pada Gambar 4.

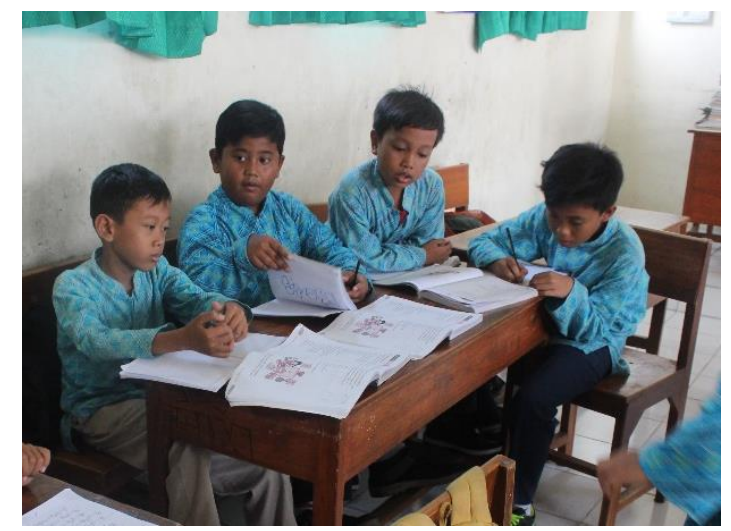

Gambar 4. Ujicoba Modul dalam Kelompok Kecil

Kelayakan modul bahasa Indonesia yang dikembangkan dapat diketahui dari hasil validasi para ahli. Hasil validasi dapat berupa skala penilaian dan saran perbaikan dari masing-masing validator. Validasi ahli diperoleh dari angket untuk menilai draf dari modul yang dikembangkan. Sementara uji coba modul dilakukan di salah satu sekolah dasar dengan melibatkan 28 siswa di kelas V. Berbagai masukan dari para ahli dan hasil ujicoba digunakan untuk memperbaiki kualitas modul sehingga modul bahasa Indonesia dengan materi narasi berbasis local wisdom benar-benar layak untuk digunakan. Adapun hasil dari kelayakan modul pada Tabel 3.

Tabel 3. Hasil kelayakan Modul

\begin{tabular}{llcl}
\hline Subjek & $\begin{array}{l}\text { Komponen } \\
\text { Kelayakan }\end{array}$ & $\%$ & Kriteria \\
\hline $\begin{array}{l}\text { Ahli } \\
\text { Materi }\end{array}$ & Isi & 89 & $\begin{array}{l}\text { Sangat } \\
\text { layak }\end{array}$ \\
\cline { 2 - 4 } & Kebahasaan & 87 & $\begin{array}{l}\text { Sangat } \\
\text { layak }\end{array}$ \\
\cline { 2 - 4 } & Sajian & 82 & $\begin{array}{l}\text { Sangat } \\
\text { layak }\end{array}$ \\
\hline $\begin{array}{l}\text { Ahli } \\
\text { media }\end{array}$ & Bahan ajar & 83 & $\begin{array}{l}\text { Sangat } \\
\text { layak }\end{array}$ \\
\cline { 2 - 4 } & Gambar/ & 81 & $\begin{array}{l}\text { Sangat } \\
\text { layak }\end{array}$ \\
\cline { 2 - 4 } & kegrafikan & 82 & $\begin{array}{l}\text { Sangat } \\
\text { layak }\end{array}$ \\
\hline $\begin{array}{l}\text { Hampilan } \\
\text { ujicoba }\end{array}$ & Kepraktisan & 90 & $\begin{array}{l}\text { Sangat } \\
\text { layak }\end{array}$ \\
\hline
\end{tabular}

Berdasarkan dari tabel 2 didapatkan hasil dari validasi kelayakan modul oleh ahli materi dan pembelajaran terdiri dari aspek kelayakan isi sebesar 89\% dengan kriteria sangat layak, aspek kebahasaan $87 \%$ dengan kriteria sangat layak, dan aspek sajian $82 \%$ dengan kriteria sangat layak. Sementara itu, untuk ahli media penilaian produk meliputi aspek bahan ajar sebesar $83 \%$ dengan kriteria sangat layak, aspek gambar/kegrafikan sebesar $81 \%$ dengan kriteria sangat layak dan aspek tampilan sebesar $82 \%$ dengan kriteria sangat layak. Hasil uji coba terbatas mendapat respon positif sebesar $90 \%$ sehingga modul sangat layak digunakan sebagai bahan ajar.

\section{Pembahasan}

Modul Bahasa Indonesia dengan materi menulis karangan narasi pendekatan local wisdom dikembangkan melalui tahap analisis, tahap desain, tahap pengembangan, dan tahap implementasi didasarkan pada desain pengembangan ADDIE. Tahap analisis dengan mempertimbangkan dari Kompetensi Dasar dan disesuaikan dengan kearifan lokal yang ada. Tahap desain dilakukan penyusunan modul yang meliputi peta kedudukan modul, judul modul, dan penulisan modul. Tahap pengembangan dengan pembuatan modul yang disusun atas pertimbangan aspek kualitas bahan ajar. Tahap implementasi dilakukan dengan uji coba terbatas pada siswa kelas V. Berbagai kendala yang dihadapi dalam pengembangan modul adalah mencari orisinalitas gambar/kegrafikan dan evaluasi yang disertakan di dalam modul.

Modul dikembangkan dengan pertimbangan hakikat modul menurut Depdiknas (2008: 30) yaitu: 1) suatu unit bahan yang dirancang secara khusus sehingga dipelajari oleh pelajar secara mandiri; 2) merupakan program pembelajaran yang utuh, disusun secara sistematis, mengacu pada tujuan pembelajaran yang jelas dan terukur; dan 3) memuat tujuan pembelajaran, bahan dan kegiatan untuk mencapai tujuan serta evaluasi terhadap pencapaian tujuan pembelajaran. Karakteristik modul dikembangkan sesuai penyusunan modul Surya Dharma (2008: 3) terdiri dari:1) Self Instructional; 2) Self Contained; 3) Stand 
Alone; 4) Adaptive; 5) User Friendly. Local wisdom yang dimuat ke dalam modul mengangkat tentang rumah adat dan pakaian adat yang berasal dari Yogyakarta. Hasil studi Wafiqni \& Nurani (2018) mengemukakan bahwa penanaman potensi lokal pada siswa dapat dilakukan dengan mengintegrasikan pada pembelajaran tematik. Hal tersebut mendukung akan pengintegrasian kearifan lokal yang digunakan pada modul, sehingga siswa akan membangun koneksi dan memahamkan dirinya dengan segala potensi yang ada disekitarnya.

Hasil dari kelayakan ahli materi secara keseluruhan sangat layak dari aspek yang meliputinya. Dengan demikian, modul bahasa Indonesia yang dikembangkan memiliki kualitas yang mampu untuk digunakan. Sementara itu, pada kelayakan ahli media juga secara keseluruhan sangat layak digunakan. Berdasarkan hasil dari uji coba terbatas pada modul yang dikembangkan mendapatkan presentase sebesar $90 \%$ hal ini mengindikasi bahwa modul yang dikembangkan memiliki kepraktisan pada penggunaannya bagi siswa. Hal tersebut senada dengan penelitian yang dilakukan oleh Johariyah (2015) dengan hasil penelitian pengembangan bahan yang berorientasi pada pendekatan saintifik pada pembelajaran menulis narasi untuk siswa kelas V Sekolah Dasar adalah layak dan efektif untuk digunakan.

\section{KESIMPULAN}

Modul Bahasa Indonesia dengan materi menulis karangan narasi berpendekatan local wisdom untuk kelas $\mathrm{V}$ sekolah dasar telah dikembangkan dengan desain pengembangan ADDIE. Adapun pada tahap pengembangan terdiri dari analysis, design, development, dan implementation. Pengembangan ini hanya sampai pada tahap implementation dengan uji coba terbatas. Hasil dari pengembangan didapatkan kelayakan dengan kriteria sangat layak pada ahli materi dan ahli media. Sementara kepraktisan modul dari hasil uj icoba juga didapatkan hasil sangat layak. Berdasarkan dari perolehan tersebut modul Bahasa Indonesia yang dikembangkan bisa digunakan. Modul ini berbasis dengan local wisdom tentang pakaian dan rumah adat yang ada di Yogyakarta sebagai bahan penunjang materi dalam modul dan untuk memberikan pehamanan kepada siswa akan kearifan lokal yang ada di daerahnya

\section{REFERENSI}

Anwar, M. F. N., Ruminiati, R., \& Suharjo, S. (2017). Pengembangan Modul Pembelajaran Tematik Terpadu Berbasis Kearifan Lokal Kabupaten Sumenep Kelas IV Subtema Lingkungan Tempat Tinggalku. Jurnal Pendidikan: Teori, Penelitian, dan Pengembangan, 2(10), 1291-1297.

Asip, M., Muktadir, A., \& Koto, I. (2019). Pengembangan Bahan Ajar Bahasa Indonesia Berbasis Cerita Rakyat Untuk Mendukung Gerakan Literasi Sekolah Di Kelas Rendah. Jurnal Pembelajaran dan Pengajaran Pendidikan Dasar, 2(1), 83-97.

Cutler, L., \& Graham, S. (2008). Primary grade writing instruction: A national survey. Journal of Educational Psychology, 100(4), 907.

Deviana, T. (2018). Analisis Kebutuhan Pengembangan Modul Pembelajaran Berbasis Kearifan Lokal Kabupaten Tulungagung Untuk Kelas V SD Tema Bangga Sebagai Bangsa Indonesia. Jurnal Pemikiran dan Pengembangan Sekolah Dasar (JP2SD), 6(1), 47-56.

Johariyah, J. (2015). Pengembangan Bahan Ajar Berorientasi pada Pendekatan Saintifik dalam Pembelajaran Menulis Narasi untuk Siswa Sekolah Dasar. METAFORA, 2(1).

Kellogg, R. T. (2008). Training writing skills: A cognitive developmental perspective. Journal of writing research, 1(1).

Keraf, Gorys. (2007). Argumentasi dan Narasi. Jakarta: PT Gramedia Pustaka Utama.

Muslich, Masnur. 2010. Text Book Writing. Yogyakarta: Ar-Ruzz Media.

Nisa, Hany. (2019). Pengembangan Bahan Ajar Bahasa Indonesia Berbasis Kontekstual Untuk Siswa Kelas V 
Sekolah Dasar. Jurnal Cakrawala Pendas. 5.

Prastowo, A. (2013). Panduan Kreatif Membuat Bahan Ajar Inovatif. Yogyakarta: Diva Press.

Saputra, G. A. S. (2013). Enhancing local wisdom through local content of elementary school in Java, Indonesia. Proceeding of the Global Summit on Education, 614-620.

Solchan, T.W., Mulyati, Y., Syarif, M., dan Yunus, M.. (2011). Pendidikan Bahasa Indonesia. Jakarta: Universitas Terbuka.

Stephanie M. C. (2010) Narratives as Learning Tools to Promote School Readiness. Early Education \& Development. 21(3), 287-292. DOI: 10.1080/10409289.2010.485532

Sugiyono, E. I. (2014). Pengembangan Bahan Ajar Menyimak Berbasis Multimedia Interaktif dalam Model Belajar Mandiri untuk Sekolah Menengah Pertama. Seloka: Jurnal Pendidikan Bahasa dan Sastra Indonesia, 3(2).

Sugiyono. 2007. Metode Penelitian Pendidikan Pendekatan Kuantitatif, Kualitatif, dan R\&D. Bandung: Penerbit Alfabeta.

Sun, L., \& Nippold, M. A. (2012). Narrative writing in children and adolescents: Examining the literate lexicon. Language, speech, and hearing services in schools.

Tarigan, H. G. (2008). Membaca Sebagai Suatu Keterampilan Berbahasa. Bandung: Angkasa.

Wafiqni, N., \& Nurani, S. (2018). Model Pembelajaran Tematik Berbasis Kearifan Lokal. AL-BIDAYAH: Jurnal Pendidikan Dasar Islam, 10(2), 255270. 